\title{
Trade war looms over gene-altered foods
}

Paris. The European Parliament, the parliamentary assembly of the European Union (EU), has adopted a resolution calling for genetically modified products to be labelled as such and sold separately from nonmodified products.

The move represents a boost to an international boycott of genetically modified soya beans and maize by more than 300 consumer, health, trade and farming organizations. But it sets the parliament on a collision course with European governments, most of which favour labelling products only where they are substantially modified.

It also raises the prospect of a trade war with the United States, as any move to ban the import of foodstuffs that cannot be labelled in the way the parliament is calling for could be declared illegal under the rules of the World Trade Organization (WTO), which has taken on responsibility for the General Agreement on Tariffs and Trade (GATT). The rules allow exclusion only on strictly scientific grounds.

The parliament is still a long way from having its demands incorporated into EU legislation. Labelling is included in the European Commission's draft legislation on novel foods, and the parliament's stance is at odds with that of the council of ministers, which represents the EU member states. At present, only Austria, Germany, Denmark and Sweden support full labelling.

A political stalemate is therefore highly likely, as the parliament and the council need to agree on the legislation if it is to be adopted.

But, whatever the outcome, some observers argue that mounting public support for labelling represents a direct challenge to both international trade law and the practices of regulatory authorities. Labelling brings with it the right to choose what sort of foods to buy, not only on safety grounds but also on others such as opposition in principle to genetically modified organisms.

Regulatory authorities, under pressure from biotechnology and food companies, have until now refused systematic labelling unless the product is "substantially modified". They argue that labelling would tend to stigmatize biotechnology, while providing little useful information to consumers.

The current controversy centres on the fact that this year's exports of US soya beans to Europe contain a small proportion of Monsanto's genetically modified product, leaving importers with the choice of accepting the mixed shipments or refusing all US imports of soya beans.

The European Commission, which has already approved the marketing of the beans, will decide next month whether to approve Ciba's modified maize. If it does not, it will similarly need to ban all US maize imports - which again contain modified material - and risk triggering a trade war.

The possibility that the commission will reject Ciba's maize (which has been approved in the United States, Canada and Japan) cannot be discounted, according to observers. The UK Advisory Committee on Novel Foods and Processes is concerned about the safety of a marker gene in the maize that confers resistance to antibiotics. Given that this dissent exists, it would not be abnormal for "the doubt to prevail", says Axel Kahn,

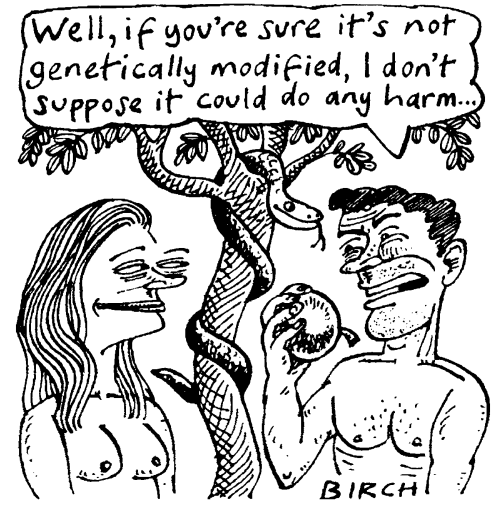

head of France's Commission du Génie Moléculaire (which has approved the maize). "If the European Commission opposed the product it would not shock me at all."

The commission is under pressure following the public opposition to imports of modified soya beans. Many food retailers, such as the UK Iceland Group, are supporting the consumer campaign for labelling, while some importers have refused all US soya bean exports - Unilever Germany, which usually accounts for 7.5 per cent of all EU imports of US soya beans, has done so, for example. Nestlé last week also bowed to consumer pressure and said it would label genetically modified produce "where reasonable and practicable".

According to Jeremy Rifkin, director of the Foundation for Economic Trends, a US lobby group, and long-time critic of genetic engineering, the fact that grain dealers are taking action beyond that required by international trade law shows that the law is out of step with the needs of consumers and the retailers wanting to satisfy their needs.

"This issue of soya and corn labelling is the lightning rod issue that will test our trade agreements," says Rifkin. "If trade agreements come up against consumer sovereignty, they are going to have to give way," he says, adding that such agreements need to be more open to public health concerns.

Others, such as Marie-Angèle Hermitte, an academic legal expert at the French Centre National de la Recherche Scientifique, argue similarly that the focus of trade agreements on the principle of free trade places excessive responsibility on countries to prove that a risk exists in cases where they seek to control the movement of goods on public health and safety grounds.

In practice, agreements reached in the most recent round of GATT negotiations have greatly reduced the scope for individual countries to ban imports on public health grounds. The changes were felt necessary to curb the misuse of such arguments as a pretext for protectionist measures.

Under the rules of the WTO, countries may not refuse imports or demand that they be labelled, for example, unless they can show that they fail to meet agreed standards where these exist, or otherwise present firm scientific evidence of a risk.

If the EU were to bow to consumer pressure and label genetically modified products, the United States could argue that this was a disguised barrier to trade "in that the labels could be seen as a means of scaring people into buying European alternatives", says Phil Evans from the UK Consumers' Association, which supports full labelling.

WTO regulations also state that countries cannot discriminate between identical products by labelling them differently. The organization has ruled, for example, that tuna caught in a way that kills dolphins cannot be labelled differently from that caught in a way that does not, according to Sabrina Shaw, an economic adviser in the WTO's trade and environment division.

WTO has not specifically considered genetically modified products, however. Shaw adds that it is unclear, for example, whether this precedent would apply if genetic changes were detectable in the final modified product.

Shaw points out that trade laws can favour public health by obliging countries to harmonize their domestic standards with international standards. WTO rules also allow a country to invoke higher standards than the international norm, but it must provide scientific evidence in support of its case, and also must apply the higher standards to its domestic industry as well as to imports.

Some are confident that, even if the commission were to reject Ciba's maize, it could still avoid a showdown with the United States. "If we had scientific advice which would give us some arguments of a risk, we would be in a good position," says one official from the European Commission, adding that much would depend on whether the United States would be simply "unhappy” or complain to the WTO.

Stephen Smith, managing director of Ciba Seeds UK, is philosophical about the prospects that the commission might reject its application. "Once the commission makes its decision we will take stock and see where we will go," he says. "If the commission refused, it would be a setback but it would be surmountable." Declan Butler 